\title{
Article \\ Identification of Factors Affecting Risk Appetite of Organizations in Selection of Mega Construction Projects
}

\author{
Sanna Ullah ${ }^{1, *}$, Nadeem Ahmad Mufti ${ }^{1}$, Muhammad Qaiser Saleem ${ }^{1} \mathbb{D}$, Amjad Hussain ${ }^{2}$, Rab Nawaz Lodhi ${ }^{3}$ \\ and Rehan Asad ${ }^{1}$ \\ 1 Department of Industrial \& Manufacturing Engineering, University of Engineering \& Technology, \\ Lahore 54890, Pakistan; namufti@uet.edu.pk (N.A.M.); qaiser@uet.edu.pk (M.Q.S.); \\ 2017phdem1@student.uet.edu.pk (R.A.) \\ 2 Department of Mechanical Engineering, University of Engineering \& Technology, Lahore 54890, Pakistan; \\ chamjad@uet.edu.pk \\ 3 UCP Business School, University of Central Punjab, Lahore 54782, Pakistan; rabnawaz.lodhi@ucp.edu.pk \\ * Correspondence: sannaullah@uet.edu.pk; Tel.: +92-332-4653996
}

check for

updates

Citation: Ullah, S.; Mufti, N.A.; Qaiser Saleem, M.; Hussain, A.; Lodhi, R.N.; Asad, R. Identification of Factors Affecting Risk Appetite of Organizations in Selection of Mega Construction Projects. Buildings 2022, 12, 2. https://doi.org/10.3390/ buildings 12010002

Academic Editors: Agnieszka Leśniak and Krzysztof Zima

Received: 22 November 2021 Accepted: 19 December 2021

Published: 21 December 2021

Publisher's Note: MDPI stays neutral with regard to jurisdictional claims in published maps and institutional affiliations.

Copyright: (c) 2021 by the authors. Licensee MDPI, Basel, Switzerland. This article is an open access article distributed under the terms and conditions of the Creative Commons Attribution (CC BY) license (https:/ / creativecommons.org/licenses/by/ $4.0 /)$.

\begin{abstract}
Risk appetite is a crucial component that plays a key role in the decision-making process of project risk management. Despite rising scholarly interest in project risk management, risk appetite has received little attention thus far. A well-defined risk appetite ensures that all decisions taken throughout the course of a project are consistent with an organization's ultimate strategic aim. This research aims to identify the factors affecting the risk appetite of megaproject selection in the construction sector. The study adds to the knowledge of risk appetite in mega construction project selection and qualitatively examines the factors affecting risk appetite. Exploratory research design is used to identify these factors. The factors are identified using semi-structured interviews of 30 practitioners from the top and middle management working on mega construction projects. Thematic analysis was performed using NVIVO academic software. The most highlighted factors are financial attributes, board of directors' agility, political factors, project location and demographics. The proposed conceptual framework identifies the factors affecting the risk appetite of mega construction project selection. These factors may be utilized as a starting point by construction project organizations to evaluate the risk appetite of a mega construction project. Risk appetite-based project selection will decrease chances of failures, delays, and cost overruns in mega-projects. These factors can be used by researchers as a rationale for developing predictive or descriptive models of project selection based on risk appetite.
\end{abstract}

Keywords: project management; project risk management; risk appetite; mega projects; construction projects

\section{Introduction}

Mega construction projects have a substantial impact on communities. Mega projects are characterized by significant structural, political, technological, and socio-economic complexity and extended execution times. These challenges are difficult to manage using traditional methods [1-5]. A diverse variety of organizations, from the origin to the operational stage of a megaproject, participate in different and interrelated unique activities to guarantee the effective execution of the project $[2,6,7]$.

The importance of megaprojects' developmental benefits cannot be overstated, despite their troubled history of poor performance [1,8,9]. Megaprojects raise uncertainty and present severe challenges for inventive companies due to unexpected and developing concerns. Mega-projects involve a wide range of stakeholders. Various stakeholders retain their own goals, expectations, interests, reasons, and strategies inside megaproject innovation ecosystems, which may or may not be aligned with the megaproject aims $[2,7,10,11]$. Megaprojects are renowned for budget overruns and failures due to their size and impact [1]. According to Merrow, 65\% mega projects fails and in some cases failure rate is 
$75 \%$ [12]. This subpar performance is already justified technologically, financially, socioeconomically, and environmentally $[8,13]$. Megaprojects require new managerial skills and structures due to its complexity, failure and cost overruns [14].

Risk is an unforeseeable event or scenario that, if it occurs, has an effect on one or more objectives, either positively or negatively. Negative risks are perceived as threats, and positive risks are perceived as opportunities [15]. Risk management procedures include risk assessment, risk identification, risk analysis, risk response planning, response implementation, and risk monitoring. The objectives of project risk management are to decrease the probability and/or impact of negative risks while increasing the probability and/or impact of positive risks in order to optimize the possibility of project success [16].

The global construction industry is expected to be worth around USD 10.5 trillion by 2023, with a compound annual growth rate of 4.2 percent between 2018 and 2023 [17]. In construction, decision-making is about making sound, not ideal, choices [18]. Mega construction projects fail or are delayed due to the risk involved in these projects. Major risks in construction projects are technical, time, design, market, legal, management, financial, design, political, environmental, social, safety, and physical [19]. Other risk factors include resource constraints, site conditions, contractual and legal construction, as well as social, political, economic, and financial factors [20].

Despite the all the associated risk with mega projects some organizations are willing to take risk to achieve their financial and strategic goals. Risk appetite of an organization is a willingness to accept associated risk of the project in order to achieve organizational and strategic goals. The degree of uncertainty that an organization or person is ready to bear in exchange for a benefit is referred to as risk appetite. Risk appetite directs risk management and the criteria by which the company decides whether or not to take on risk [15]. This likewise applies to the degree of risk that organizations and partners decide to take so as to accomplish their strategic goals. Such goals are established on the basis of the role of any entity in some project [21]. The nature, importance, and appetite for risk vary across an organization's life cycle and the life cycle of its programs and projects [15].

Hunger is not synonymous with appetite. Appetite is indeed a strong want, a cognitive necessity that should be met. Hunger is the external expression of appetite, which we experience as an absence of something and which motivates us to act to satiate the underlying need [22]. In risk management and strategic decision-making process of an organization, risk appetite is recognized as an important consideration [23]. Risk appetite enables policy makers at all levels in an organization, from the board members to project teams, to determine the assumed level of risk in a particular circumstance [22,24]. It has evolved into a critical concept in business, as corporate governance authorities increasingly require publicly listed companies to make a written statement outlining their overall risk appetite [25]. While every business has an inherent risk appetite, identifying it and evaluating its appropriateness has proved to be a major barrier for decision-makers [26]. Senior management still finds it difficult to examine and evaluate the risk appetite of the project [27]. Academic research on risk appetite has received very little attention, and no studies have been undertaken to examine the variables influencing it, particularly in the context of large building projects. Existing research on risk appetite is mostly conceptual in nature and is concentrated in the areas of economics and finance [28-32]. A little work is performed in the field of hospitality management [33-35]. The emphasis has been on discussing the concept's meaning [36], its function in risk management [23] as well as presenting several techniques to establishing a risk appetite statement [25,37].

Mega construction projects are mostly delayed or face cost overruns. Current studies show that mostly project selection is performed based on financial factors such as cost, rate of return, probability of capital return, net present worth, and available funds. It is argued that the one way to solve this problem is risk appetite-based project selection. The purpose of this study is to determine the factors which influence the risk appetite of megaprojects selection in the construction industry. Researchers fill the gap in research on the risk appetite for mega construction projects selection. Risk appetite-based project selection can 
be performed by identifying and understanding the variables affecting megaproject risk appetite. Comprehensive knowledge of these variables will assist companies in not only articulating their risk appetite statement but also in monitoring and examining risk more effectively, as well as identifying risk appetite, which will allow senior managers to alter their risk appetite proactively. The article starts by defining megaprojects, their significance, and why megaprojects fail and perform poorly. The concept of risk, risk management, and risk appetite are then defined by relating various fields of research in layers of literature pertaining to risk-taking in order to develop a conceptual framework for the factors that may influence a company's risk appetite when selecting mega construction projects. The factors are discovered through literature research and semi-structured interviews. Interviews supplement the factors identified in the literature. Conclusion and recommendations are presented for practitioners and researchers.

\section{Literature Review}

Construction projects are distinguished by their various degrees of novelty and complexity, the engagement of several stakeholders, their capital intensity, their dynamic surroundings, extended production periods, and their exposure to the external surroundings and weather changes [38]. Zou [39] developed a joint risk management tool to mitigate risks after identifying 25 key risks in the construction sector of China. The social risks of high-density urban construction projects in China were identified by the yuan [40]. A total of 16 social factors were identified and, after that, a social risk network analysis was devised to better help the Government implement effective social risk management measures. Fortunato [41] identified the safety and health risks and opportunities associated with the building components and construction procedures used to earn specific leadership in energy and environmental design credits and discovered that employees on construction projects spend more time working at heights, with electrical current, near unstable soils, and near heavy equipment than workers on traditional projects

Since the global recession around 2008, Risk Appetite as a term is being more frequently used in corporate sector [23]. Corporate governance regulators are now requiring companies in a variety of industries to explicitly describe their risk appetite in corporate governance [26]. A more in-depth discussion among board members about the level of risk they are prepared to take is believed to assist companies to make more informed and prudent risk-taking choices [36]. It is capable of effectively controlling any extreme risk-taking behaviors that were prevalent in large companies before the 2008 financial crisis [24].

Nonetheless, there is a dearth of academic studies on risk appetite. The majority of existing research on risk appetite has been conducted in economics, finance and hospitality management [42]. Risk appetite is often synonymous with popular terms such as "risk tolerance", "risk aversion", or "risk preference", and is defined as an investor's desire to purchase imperil assets $[43,44]$. Additionally, above cited researchers think that risk appetite is primarily an individual concept, rather than an organizational one and that it is associated with financial risk-taking $[45,46]$. There are a rising number of risk appetite studies in management $[23,26,36]$. Despite this, there is no consensus on how to define it $[21,23,36]$. For example, Gontarek [23] defines risk appetite as the written expression of the aggregate degree and categories of risk that a company is willing to accept or avoid in order to achieve its goals. Aven [36] describes it differently as the willingness to do risky actions in the pursuit of objectives.

Despite the fact that there is no commonly agreed definition [35,47], a widely held understanding of the term seems to be that it refers to a business' readiness to take calculated risks in order to achieve its objectives [26]. However, broad labels such as "risk-seeking" or "risk-averse" are insufficient to define this desire [36]. The desire to take risks is complicated and dynamic, depending on the kind of risk being considered and the specific circumstances [24]. The majority of existing risk appetite definitions miss the multidimensional and time-horizon features of risk appetite, causing many business executives to think that 
a company's risk appetite is unchanging and can be characterized by a single financial indicator $[21,23,36]$.

Financial factors such as cost, rate of return, return on investment, net present worth and available funds are used to select projects [48-51]. Mega construction projects are notorious for failures and cost overruns. Project selection and portfolio development in accordance with corporate strategy is an important task for decision makers in such projects. Risk appetite was defined in the present research as a company's dynamic readiness to take risks in order to achieve its goals at a particular moment. At some other point in time the company's circumstances will have changed, as will the types and extent of risk the firm is prepared to accept.

Scholars from many research areas, particularly finance/economics and psychology, have produced numerous famous hypotheses to explain people's and businesses' risk-taking behaviors and risk attitude. Some theories are modern portfolio theory [52], behavioral theory of the firm [53], prospect theory [54], threat rigidity [55], and expected utility theory [56]. According to Isen and Patrick's mood maintenance theory [57], risk perception, income, and mood are all significant factors influencing individual risk behavior. Upper echelons theory by Hambrick and Mason [58] indicates that the risk propensity of $\mathrm{CEO}$, the board of directors and the executive committee, organizational performance and remuneration are all significant determinants of a firm's risk-taking. Eisenhardt gave information systems insight, results uncertainty, incentives, and risk in agency theory [59], Kangari and Riggs described an examination of the construction project portfolio that required the characteristics of each project to be evaluated based on expected returns, risks, and correlation across all the projects [50]. The behavioral agency model indicates that executive risk management varies between modes of monitoring and may show both risk-seeking and risk-averse tendencies [60].

The following research papers tested these theories and helped to support these factors. The company's performance has shown a substantial impact on corporate risk based on whether performance fulfils the desired objective [61-63]. Remuneration, especially share options and cash incentives, is widely acknowledged as a significant driver of corporate risk-taking $[64,65]$. Risk propensity of each individual in board of director is significant [46,66-68]. The emotions of senior executives on corporate boards are also important factors. The senior management emotions also reflect the characteristics and preferences of its leadership as drivers of a risk-taking behavior and risk attitude [69,70]. A corporation may either drive or hinder nature of risk and the amount thereof [71,72].

Furthermore, some factors that have been shown to impact a company's risk appetite are its size [73,74], strategic objectives [75-77], market competition [78,79] demographics [30] and government and industry rules and regulations [80,81]. The organizational history of risk taking $[45,82,83]$ and the pressure of its stakeholders and their demands have been recognized as drivers and inhibitors at a certain moment, depending on the circumstances $[84,85]$. Other factors include enterprise environmental factors and organizational process assets. All of these factors have an impact on the project, both favorable and unfavorable [16].

While these research studies discovered a diverse variety of factors, they do not relate to one another, and hence the understanding of the drivers of risk taking is incomplete and limited to the effect of a single component. Some studies, however, take a deeper look at the effect of multiple factors on risk taking. Existing literature was integrated, and conceptual factors models that impact company risk management were presented by Bhatta [76], Baird and Thomas [75] and Pablo and Javidan [68]. Although these models included many comparable variables, they continued to categorize them and focused on the firm's features and traits, the peculiarities of people and decision-making teams, and external influences in industry or the broader corporate environment. Harwood [86] utilized a grounded-theory technique to find ten drivers of a business's risk-taking, but the labeling of those predictors was substantially different from the remainder of the research. The factors identified from literature of other research streams have been summarized in Table 1. 
In this research factors were classified into five categories organizational factors, decision-makers factors, external factors named as environmental factors, project factors, and miscellaneous factors. This classification is performed on the basis of other studies, enterprise environmental factors, and organizational process assets [16,24,35,68,87].

Table 1. Factors which can affect risk appetite.

\begin{tabular}{|c|c|c|c|c|c|c|c|c|}
\hline \multirow[b]{2}{*}{ Determinants } & \multicolumn{7}{|c|}{ Scope of the Study } & \multirow[b]{2}{*}{ Sources } \\
\hline & $\begin{array}{c}\text { Financial } \\
\text { Manage- } \\
\text { ment }\end{array}$ & $\begin{array}{c}\text { Hospitality } \\
\text { Manage- } \\
\text { ment }\end{array}$ & $\begin{array}{c}\text { Strategic } \\
\text { Manage- } \\
\text { ment }\end{array}$ & $\begin{array}{c}\text { Enterprise } \\
\text { Risk Man- } \\
\text { agement }\end{array}$ & $\begin{array}{l}\text { Public Man- } \\
\text { agement }\end{array}$ & Psychiatry & $\begin{array}{c}\text { Procurement } \\
\text { Manage- } \\
\text { ment }\end{array}$ & \\
\hline $\begin{array}{l}\text { Financial } \\
\text { attributes }\end{array}$ & $\checkmark$ & & & & & & & [28-32] \\
\hline Leverage & & $\checkmark$ & & & & & & [35] \\
\hline Risk capacity & & $\checkmark$ & & & & & & [35] \\
\hline $\begin{array}{l}\text { Risk culture } \\
\text { Risk }\end{array}$ & & $\checkmark$ & & & & & & [35] \\
\hline $\begin{array}{l}\text { management } \\
\text { capability }\end{array}$ & & $\checkmark$ & & & & & & [35] \\
\hline $\begin{array}{l}\text { Internal } \\
\text { performance }\end{array}$ & $\checkmark$ & & $\checkmark$ & & & & & [61-63] \\
\hline $\begin{array}{l}\text { Goals and } \\
\text { objectives }\end{array}$ & & & $\checkmark$ & $\checkmark$ & $\checkmark$ & & & [75-77] \\
\hline Firm size & $\checkmark$ & & $\checkmark$ & & & & & {$[73-75]$} \\
\hline $\begin{array}{l}\text { History of } \\
\text { risk taking }\end{array}$ & $\checkmark$ & & $\checkmark$ & & & & & {$[45,82,83]$} \\
\hline $\begin{array}{l}\text { Risk } \\
\text { perception }\end{array}$ & & & $\checkmark$ & & & $\checkmark$ & $\checkmark$ & {$[71,72,75]$} \\
\hline $\begin{array}{l}\text { Board risk } \\
\text { propensity }\end{array}$ & $\checkmark$ & & $\checkmark$ & & $\checkmark$ & & & {$[46,68,76]$} \\
\hline $\begin{array}{l}\text { Executive } \\
\text { committee } \\
\text { Risk } \\
\text { propensity }\end{array}$ & $\checkmark$ & & $\checkmark$ & & & & & {$[68,76]$} \\
\hline $\begin{array}{l}\text { CEO risk } \\
\text { propensity }\end{array}$ & $\checkmark$ & & $\checkmark$ & & & & & {$[66,67]$} \\
\hline $\begin{array}{l}\text { CEO } \\
\text { emotions }\end{array}$ & $\checkmark$ & & $\checkmark$ & & & & & {$[69,70]$} \\
\hline $\begin{array}{l}\text { Executive } \\
\text { remuneration }\end{array}$ & & & $\checkmark$ & & & & & {$[64,65,75]$} \\
\hline $\begin{array}{l}\text { External } \\
\text { stakeholder } \\
\text { demands }\end{array}$ & $\checkmark$ & & $\checkmark$ & & & & & {$[84,85]$} \\
\hline Competition & $\checkmark$ & & $\checkmark$ & & & & & {$[75,78,79,88]$} \\
\hline $\begin{array}{l}\text { Rules and } \\
\text { regulation }\end{array}$ & $\checkmark$ & & & & & & & {$[80,81]$} \\
\hline Demographics & $\checkmark$ & & & & & & & [30] \\
\hline
\end{tabular}

\section{Methodology}

Exploratory research [89] is used in this study to identify the factors affecting risk appetite of mega construction projects selection. In order to gain new insights for exploratory studies, in-depth semi-structured interview data collection methods $[90,91]$ were used. The researcher gave a list of themes and questions to address in semi-structured interviews, but these changed from interview to interview.

The key informant technique $[92,93]$ is used to select interviewees for a qualitative study. People who have played significant roles in their areas and have a good awareness of the specific information pertinent to the research are considered key informants. A specific set of inclusion criteria was used to identify 30 key informants as reported by Kruger and Casey [94]: the person must be working on mega construction projects in a public or private sector organization shown in Figure 1, and the organization could be a contractor, consultant, or owner. The sample size was considered sufficient in light of guidelines by Galvin [95]. 


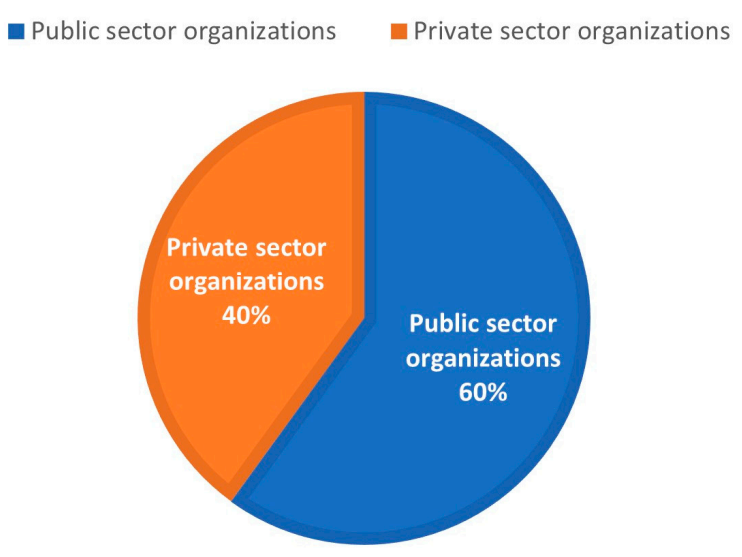

Figure 1. Sector wise segregation of respondents.

The respondents were from the owners, contractors, and consultant organizations working on mega construction projects as shown in Figure 2.

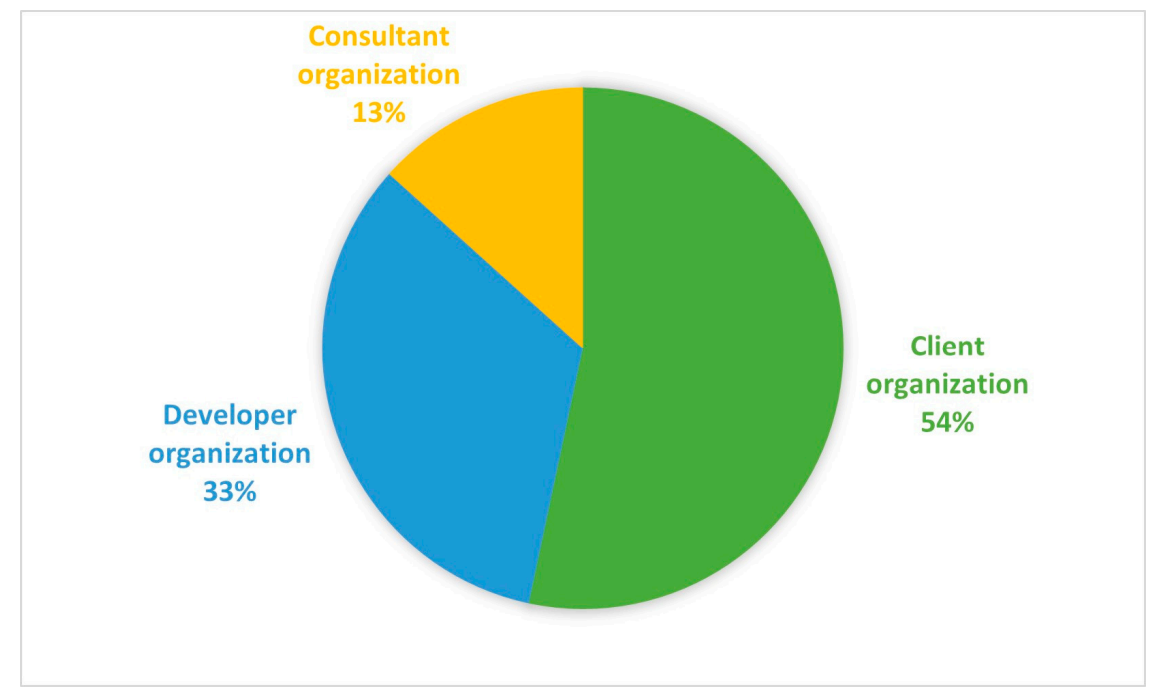

Figure 2. Role wise segregation of respondents.

Other criteria include that an interviewee must be a person working at top management or middle management shown in Figure 3.

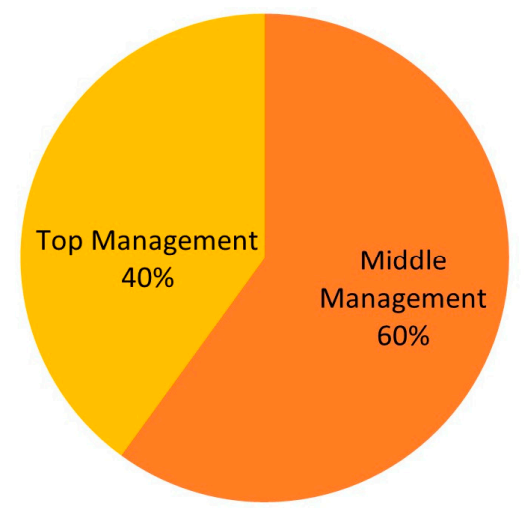

Figure 3. Management level of respondents. 
Respondent's designations were general managers, deputy sectaries, senior engineer, risk managers, directors, deputy directors, project managers and manager of planning, risk and cost control. The range of their experience varied from 8 to 35 years as shown in Figure 4.

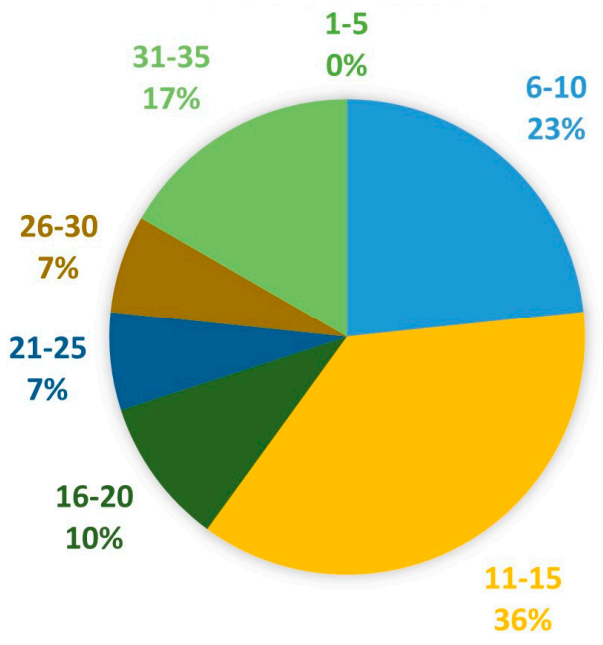

Figure 4. Experience of respondents in years.

A variety of probes and other approaches [96] were utilized to accomplish the depth of responses in terms of penetration, investigation, and explanation. The interview questions focused on respondents' thoughts on the aspects that define the risk appetite of megaproject selection. Respondents were asked about risk appetite in projects, organizational, decision makers, environmental, project and any other factors that affect risk appetite in mega construction project selection. They were also asked whether they believed that certain factors in the major categories were lacking. The interviews lasted 40 to $120 \mathrm{~min}$, and while interviewees were hesitant to digitally record owing to organizational constraints and problems, notes were taken throughout the interview, which have been subsequently transcribed verbatim and member-checked as narrated by Lincoln [97] and all modifications are treated as primary data. The semi-structured data were analyzed to determine the most relevant factors influencing risk appetite as well as any unexpected responses that varied from or contradicted the literature. The complete research methodology is shown in Figure 5.
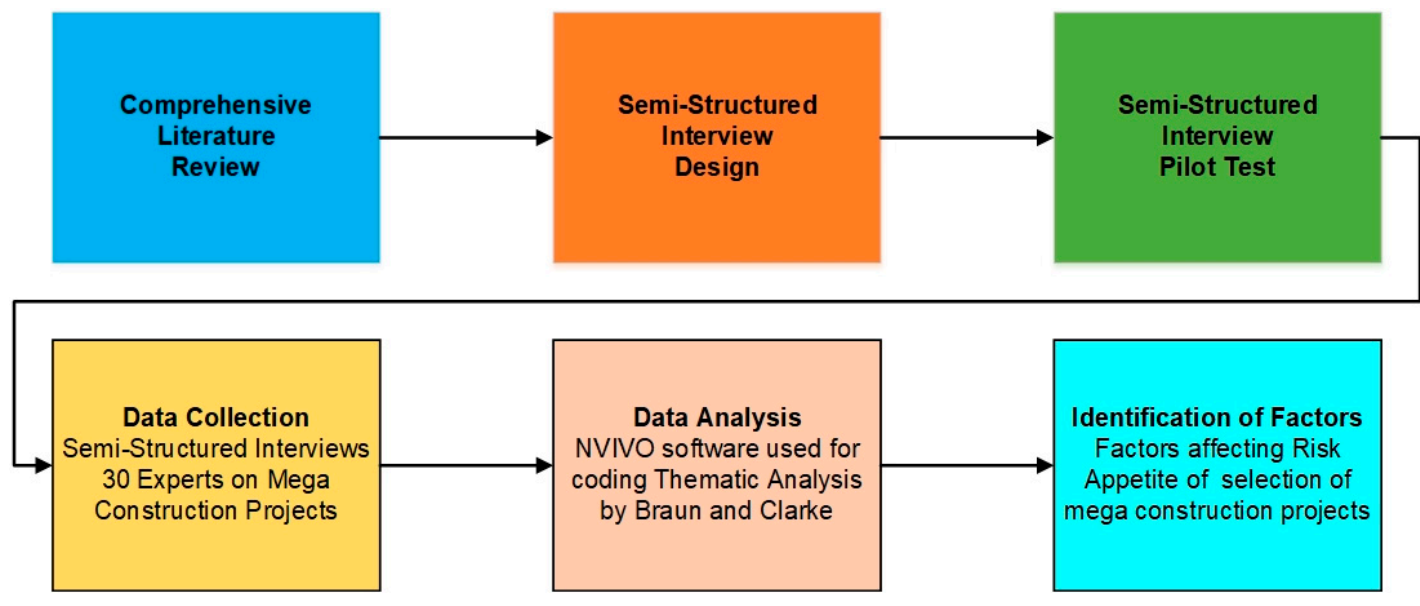

Figure 5. Flow chart of the research methodology.

Thematic analysis by Braun and Clarke [98] is used for factor identification. This analysis has six steps: familiarization of data, initial code generation, theme search, theme 
review, defining and naming themes, and generating results. The coding method included both deductive and inductive reasoning: the deductive phase started with the establishment of a basic coding structure.

Thematic analysis was performed using NVIVO academic software. Authors created a code for each component and tagged them with the same "name". Factors were grouped into five major categories organizational factors, decision-makers factors, external variables termed as environmental factors, project factors, and miscellaneous factors. The authors then went through all of the transcripts, highlighting relevant keywords, phrases, and paragraphs and adding them to the proper codes. All transcripts were inductively coded to facilitate the detection of new codes arising from the data after this deductive coding exercise. Phrases and passages that could not be categorized using existing codes were concentrated on, and new codes were built. These codes were labeled with the same term as the practitioner mentioned. This coding procedure was carried out by all the researchers together.

\section{Results and Discussion}

The study identified the factors affecting the risk appetite of an organization in the selection of mega construction projects. The semi-structured interviews provided deep insights from 30 top and middle management experts from different government and private sector organizations working on mega construction projects. Analysis of semi structured interviews were performed using NVIVO academic software The following highlights the key factors derived from the semi-structured interview; "parent codes" and "child codes". The parent codes were organizational, decision-makers, environmental, project factors, and any miscellaneous factor which did not lie in previous categories. The respective parent codes are shown in the Figure 6.

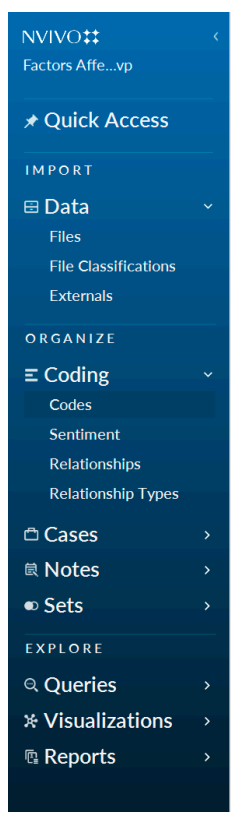

SANNAULLAH 61 Items

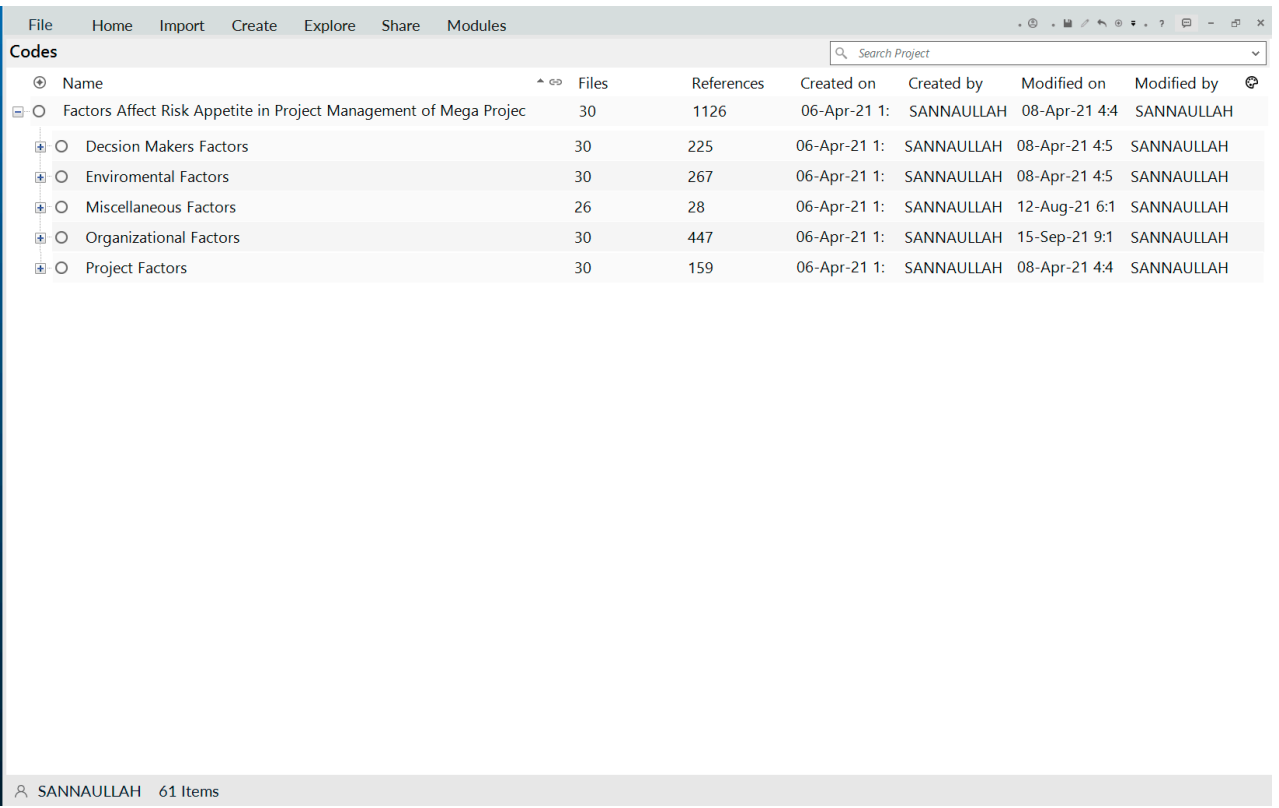

Figure 6. NVIVO codes.

The factors found in the literature were discussed in depth during the semi-structured interviews, which were supported by the concept of each perspective. A word cloud is shown in the Figure 7 which highlights the importance of the factors according to practitioners' point of view. 


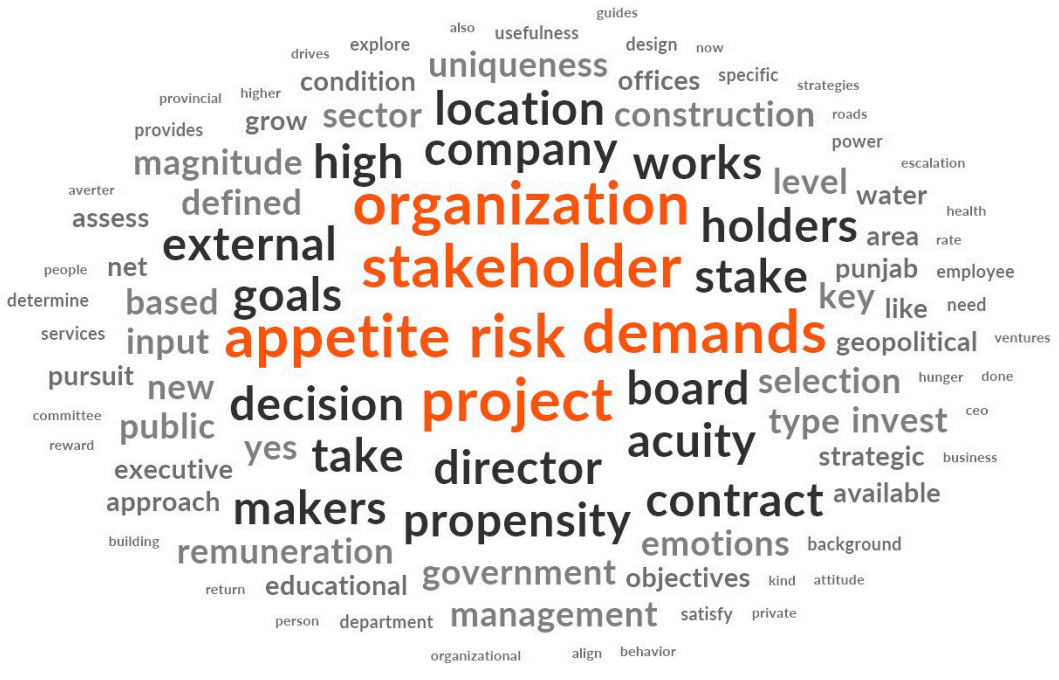

Figure 7. NVIVO codes words cloud.

The following sections present an analysis of the factors and their different perspectives. To maintain anonymity, participants are assigned to the order in which they were interviewed. The experts highlighted many organizational factors shown in Figure 8. The top three factors are financial attributes, organizational history of risk-taking and organizational risk culture. Factors that were identified from the literature were confirmed in the interviews and also some new factors were identified.

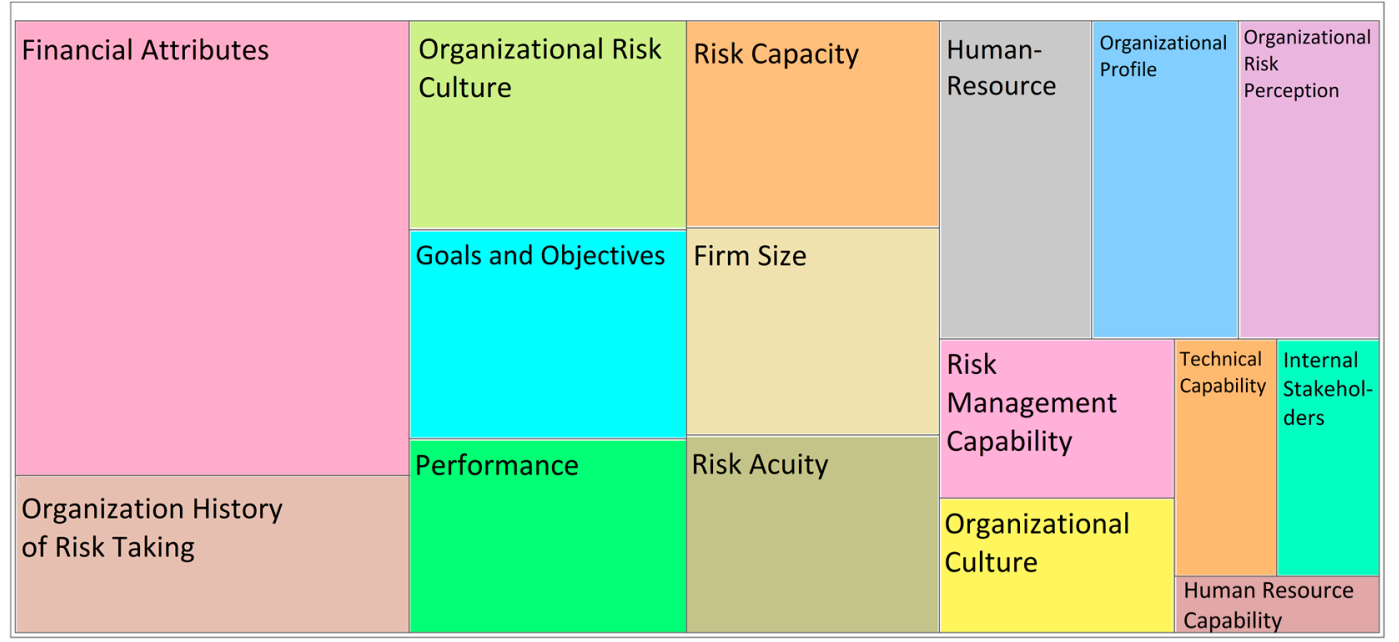

Figure 8. Hierarchy chart of organizational factors.

The financial attributes include leverage, cost to benefit ratio, equity to debt ratio, and available finance to carry out the project. All the interviewees mentioned financial factors. Financial factors are the initial factors that drive risk appetite. Previous studies show that project selection is performed only on the basis of financial factors [48-51]. Most mega projects are cost overrun, delayed, and poorly performed [1,7,9], so every organization tries to obtain a better understanding of financial factors to achieve equilibrium in finances and to calculate the cashback period. For public sector organization the cost to benefit ratio and available finance are important. When enough funds are not available to complete the project, the organization takes debt. A highly leveraged firm is likely to be particularly cautious when it comes to risk-taking, because any needless risk-taking actions if failed, may substantially impair the company's capacity to repay its debt. A firm with a low 
amount of debt does not have the same fear, and, as a result, it may be more comfortable pursuing developing possibilities and taking on more risk.

The organizational history of risk-taking has a significant impact on risk appetite $[45,82,83]$. Most of the practitioners have a consensus that the organizational history of risk-taking defines the risk attitude and ultimately the risk appetite of the organization in mega construction project selection. History of risk taking is an important factor for project selection involving higher risk. A successful track record of risk-taking improves risk appetite because it instills confidence in senior management. A weak track record, on the other hand, is more likely to lower risk appetite since it indicates that the firm is not as successful in recognizing and managing risks. Executives anticipated that a strong previous track record of successful risk-taking would have a different effect on risk appetite than a strong prior track record of failed risk-taking.

Organizational risk culture was identified by twenty-seven interviewees. It is the third in the ranking of organizational risk factors. It is an important factor that influences the risk appetite of an individual or an organization while selecting a project [35]. Specific risk categories that an organization prefers are defined by the organization's risk culture and are comfortable with the quantity of risk, and risk appetite. The organizational risk culture is often regarded as the common values and beliefs of a firm in risk and its significance in the decision-making process. Several respondents asserted that the culture of risk of each firm depended on their distinctive making up organization.

Organizational goals and objectives also impact the risk appetite of the organization while selecting the project [75-77]. Projects are the bread and butter of project-based organizations, and to achieve the strategic objective of the organization, the organization must consider the projects that it has chosen. The organization that is more ambitious about growing itself and earning a profit takes more risk and its risk appetite increases to achieve its strategic goals. Ambitiousness drives the organization to take risky decisions to grow and earn and compete with its competitors. Project selection must be aligned with the portfolio and, its strategic goals and objectives [99-102].

The performance also affects the risk appetite of the decision of the project selection [61-63]. Organizations with well-established history accept the calculated risk, whereas new entrants may take the greater risk for growth, which increase their risk appetite. However, their risk attitude might be unconstrained if the survival of new entrants or low-level firms is jeopardized. However, when the survival of new entrants or low-achieving companies is threatened, their risk attitude might be risk-averse.

Risk capacity influences the risk appetite of the organization in project selection [35]. Risk capacity is an organization's maximum risk-bearing capacity in the pursuit of its goal. Risk capacity is the absolute maximum financial or monetary risk that an organization can take. Risk capacity must be aligned with the objectives, resources, and risk appetite of an organization. Some other organizational factors are firm size (the size and scope of an organization and its operation) [73-75], risk acuity (organizational agility to understand risk), the organization's profile in terms of its working domain and the types of projects on which they are working.

Human resources play an important role in project management and have a positive impact on project success $[103,104]$. An organization with a more plentiful, competent, sound, and technical workforce has more risk-taking behavior. A firm with little human and technical resources has less risk appetite for mega construction projects. Organizational perception of risk (how they perceive risk, whether it is positive or negative) $[71,72,75]$, risk management capability (specific types of risk that a business is willing to take, based on its competencies and the specific risks it specializes in managing), internal stakeholders [100], and the organizational culture in terms of its working style and overall management style affect risk appetite.

The participants highlighted some decision makers factors shown in Figure 9. Factors that were identified from the literature were confirmed in the interviews and also some new factors were identified. The top three factors are board of director risk acuity, risk appetite of 
decision makers and C.E.O risk propensity. Other factors are board of directors' input, C.E.O emotions, board of director risk propensity, remuneration of executive members, C.E.O risk acuity, educational background of board of directors and board of directors' emotions.

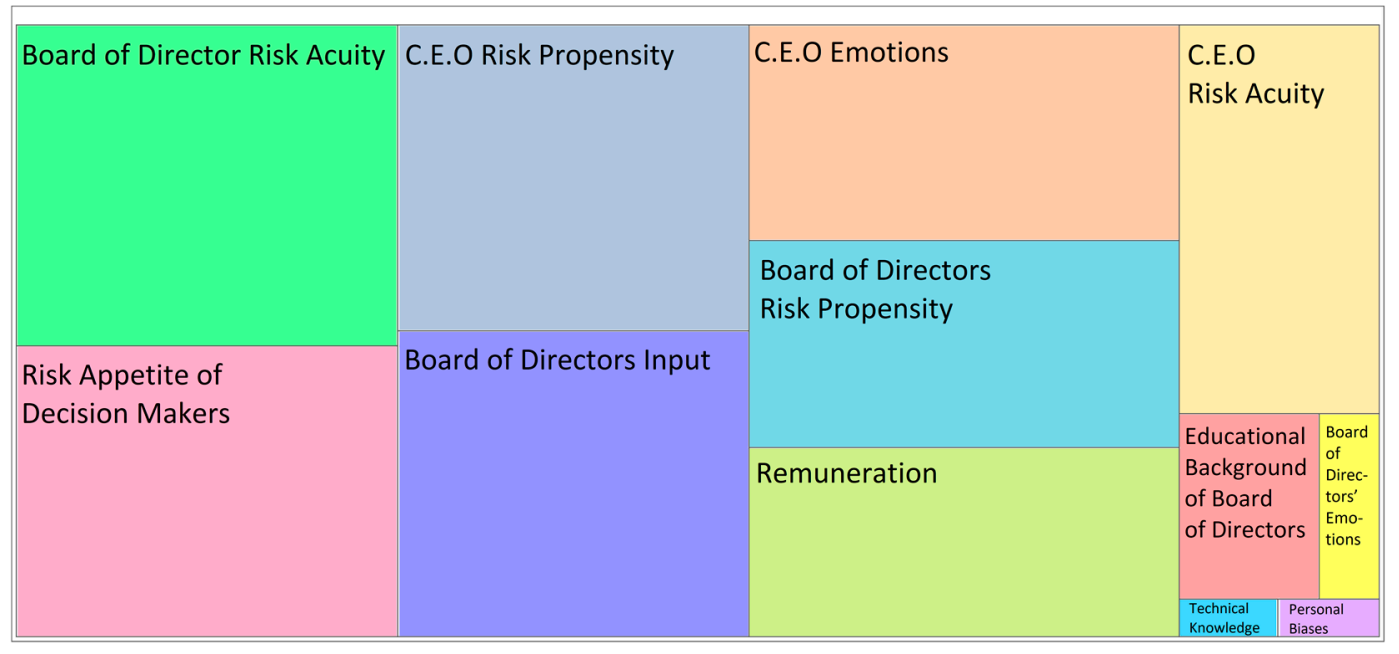

Figure 9. Hierarchy chart of decision maker factors.

The risk acuity of the board members is the top mentioned factor in the decision makers factors. Practitioners define risk acuity as the agility of board members to understand risks in the selection of mega construction projects. Risk acuity defines the attitude of the individual board members to how sharply they see the risk and reward, behind the reward which can benefit their organization. This factor is not mentioned in the previous research. The risk appetite of the key decision-makers define the risk attitude and risk preferences of the board members $[22,24,46]$. Risk appetite of decision maker is a trend and attitude in a particular circumstance in which a person takes a risk. According to the responses, this is an important factor while selecting a megaprojects.

C.E.O risk propensity is the factor that influences the risk appetite of project selection in mega construction projects. This factor depicts the willingness of the C.E.O to take risk. This factor is also recognized by literature [66,67]. The board of directors' input is also an important factor that affects risk appetite. In attaining its strategic target, the board members determine the type and amount of the considerable risk they are prepared to assume. C.E.O emotions play an important role in affecting risk appetite in the context of mega construction project selection $[35,46,69,70]$.

The C.E.O has a broader impact on the whole project selection, while other board member's risk propensity also adds to the decision with the C.E.O emotions $[46,68,76]$. Other factors are remuneration, educational background of decision makers and board members, and emotions of board members and executive committee. These factors are also endorsed in literature which affects risk appetite and decision making [30,35,64,65,75].

The interviewees highlighted some environmental factors shown in Figure 10. The top three environmental factors are politics, external stakeholders, and rules and regulations. Other environmental factors that can influence risk appetite include public opposition, level of competition, local culture, competitors, market position, legal and regulatory requirements, sustainability goals, and taxation. 


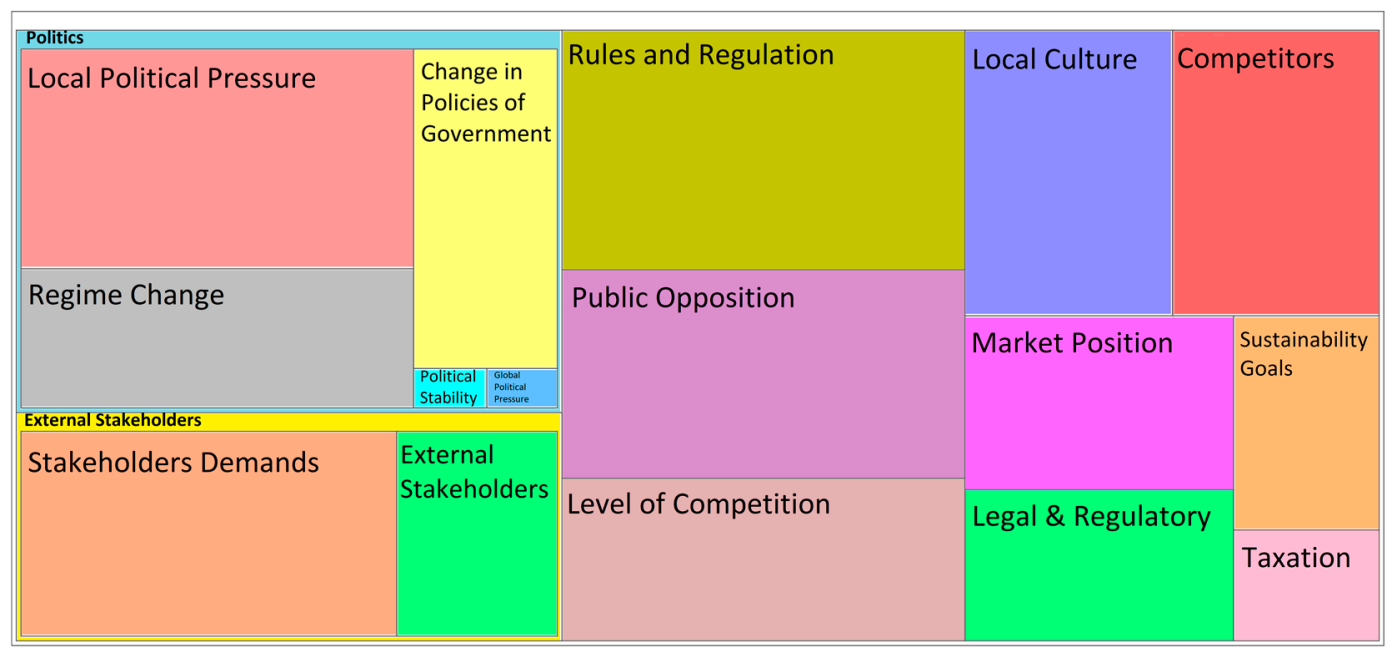

Figure 10. Hierarchy chart of environmental factors.

Politics is the factor that is mentioned most among the environmental factors in one way or the other. Political factors include local political pressure within the country, regime change, change in policies of government, political stability and global political pressure. Political factors affect risk appetite because these are the most influential factors in project success. Politics affects project success and practitioners also identified it as a risk appetite factor in selection of megaprojects [105]. Failures are very common in mega projects for many reasons, and some of the many reasons are political ruling, political policies, regime change, and external political pressure. These policies are made on the basis of the ruling political parties and the personal biases of the head of the state. These factors influence the risk appetite of project selection in mega construction projects.

External stakeholder is a factor which include external stakeholder themselves and their demands which affect risk appetite of megaproject selection. In some cases, stakeholders increase risk appetite and, in some cases, they decrease risk appetite $[84,85]$. In mega construction projects, stakeholders are funding agencies (such as the United Nations, European Union, World Bank, Asian Development Bank), owners of the project, contractors, consultants, and shareholders in the case of private limited companies involved. Private shareholders want a higher rate of return, so they have higher risk appetite. End-users of the projects and every stakeholder demands different objectives and different risk appetites and risk attitudes to obtain more benefits, while the owner organization, consultant, and contractor try to select a win-win situation for every stakeholder. The rules and regulations hinder the risk appetite [80,81].

Public opposition decreases the risk appetite of the decision-makers and an organization to select a project. Public opposition can direct to failure if not addressed [87,106], so this factor reduces the risk appetite. The level of competition and competitors is also a factor in risk appetite. These drivers encourage new entrants to take more risks as compared to those organizations that have stable performance and are well known in the market $[35,75,78,79,88]$.

Local culture can increase or decrease risk appetite. When an organization has to select a project in a faraway area or a rural vicinity, culture and common beliefs can reduce the risk appetite of project selection or vice versa [107-109]. Some other environmental factors are market position, legal and regulatory and sustainability goals. While selecting a project, a multinational organization has to think about these factors because every country and region has different legal and regulatory issues [110,111], market position [35,78], and sustainability standards $[112,113]$. These factors decrease multinational organizations risk appetite in most projects.

Project specific factors shown in Figure 11 are very important to identify. These factors all contribute significantly in determining the risk appetite of project-based com- 
panies engaged in mega construction projects [87]. The project factors identified from semi-structured interviews are project location or site, project magnitude, contract type, uniqueness, geopolitical condition, usefulness, project escalation, and technical feasibility.

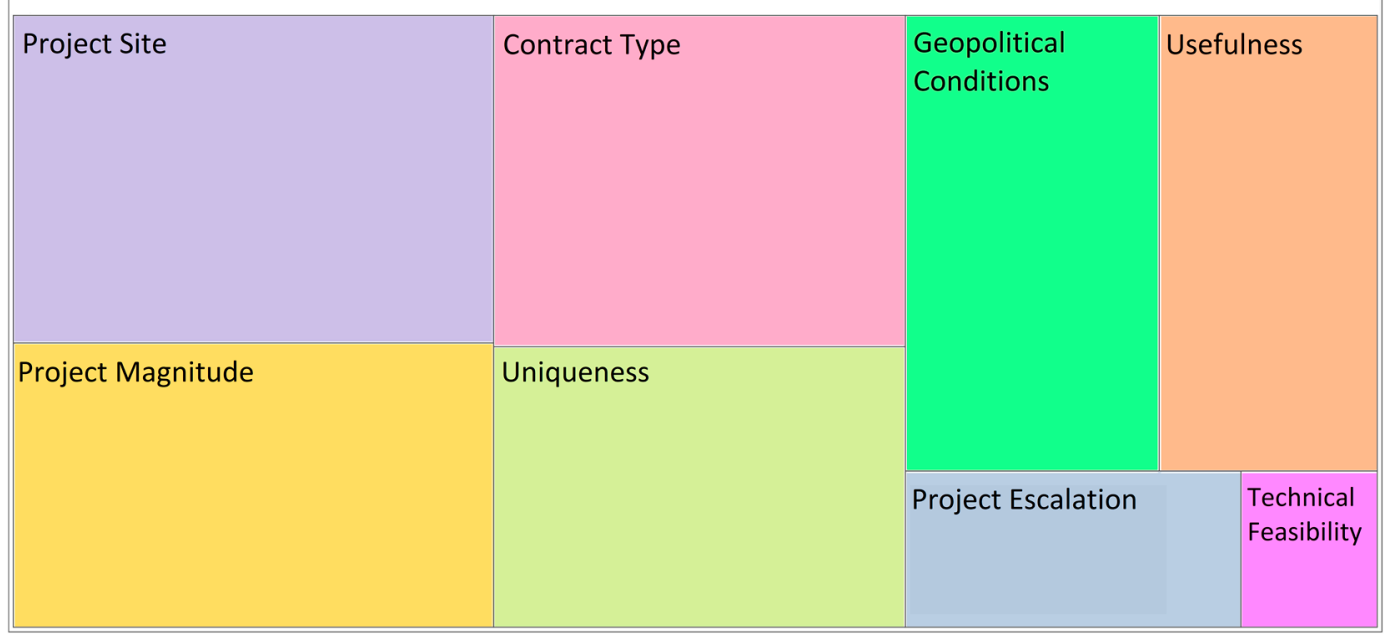

Figure 11. Hierarchy chart of project factors.

Project location is a very important driver of risk appetite for project-based organizations. This factor is identified as the most important factor among project factors by the respondents. This factor is also a question for many researchers about what will be the optimal project location or how to place a project in a feasible and optimal location [114-118]. Project location can either increase or decrease the risk appetite of project selection. Practitioners find project location the most important project factor while defining the risk appetite of a mega construction project. Project size is another factor that affects risk appetite. As the project size increases, complexity increases in the project, and in mega projects, this complexity can lead to failure $[1,8,14,119]$. Organizations consider project magnitude to avoid failure and delays.

Some other factors which affect the risk appetite are contract type, uniqueness [120], and usefulness. These actors are not identified in literature from the perspective of risk appetite. Contract type also acts as a driving factor that can decrease or increase the risk appetite. Some organizations' risk appetite increases in build-operate-transfer (BOT) projects and others risk appetite increase in public-private partnership projects. For private organizations, it is uniqueness, which increases their risk appetite because it will be the selling and revenue generating point for bringing something unique. For public sector organizations, it is the usefulness of the project for the public and how many people receive a benefit from the project. Such projects include such as road networks, dams, powerplants, etc. Project escalation is the factor that may drive higher risk appetite, but this factor has received less attention and has not been discussed in the literature in the perspective of project risk appetite. Organizations that have failed to achieve project goals in the past and had to do project escalation to close the project will take higher risks in the future [121,122]. The least identified factor in the interviews is technical feasibility. First, technical feasibility is prepared for different available projects and defines risk appetite according to available project alternatives, and project selection is performed from these alternatives.

The last set of factors are miscellaneous factors shown in Figure 12 which do not lie in the any specific set of domains defined earlier. Demographics of stakeholders, including gender, knowledge and education, also affect risk appetite of project selection in mega construction projects $[30,118]$. 


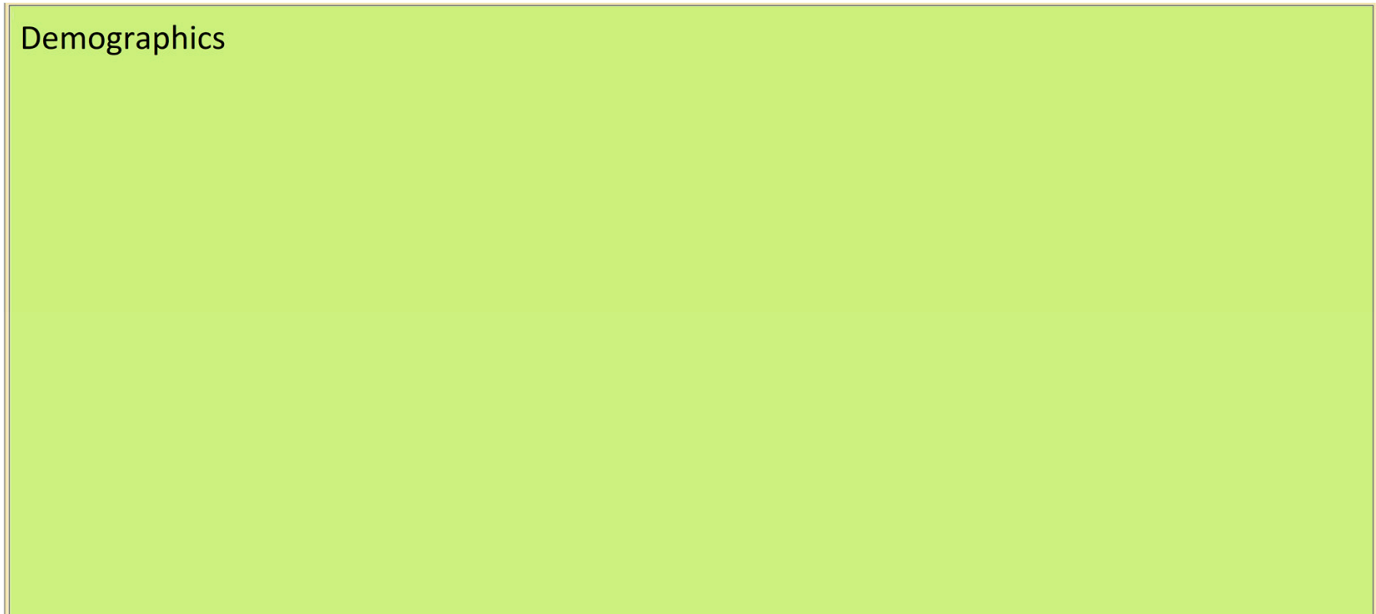

Figure 12. Hierarchy chart of miscellaneous factors.

A conceptual framework shown in Figure 13 is devised based on identified factors to have a better understanding of these factors regarding how they affect the risk appetite of an organization in megaproject selection. Megaprojects are mostly delayed, or cost overrun due to complexity and size. This framework will help an organization and its decision-makers to obtain a better insight into these factors while selecting a mega construction project.

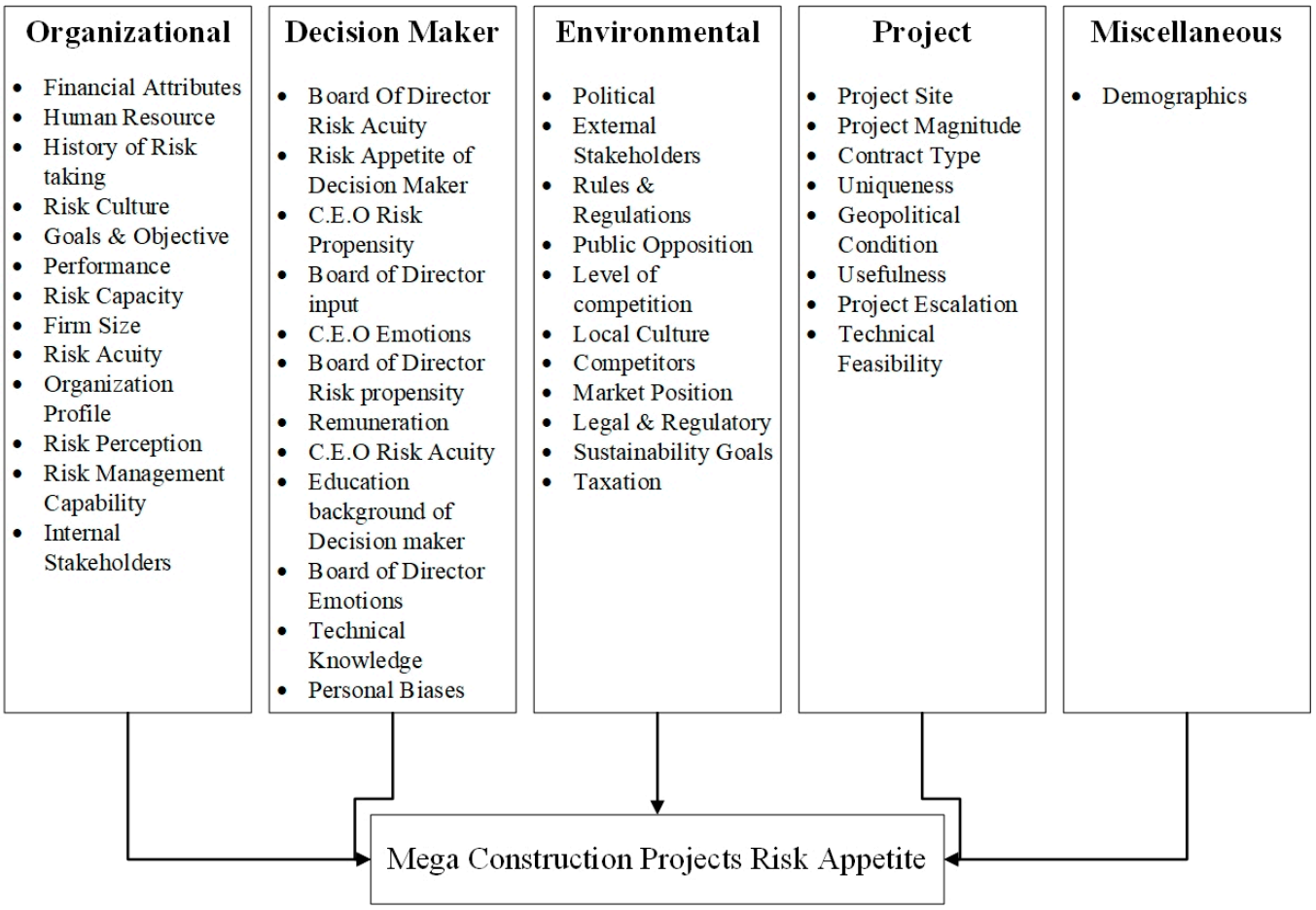

Figure 13. Framework of factors affect risk appetite in mega construction projects.

\section{Conclusions}

The purpose of this study was to identify and investigate the variables that influence risk appetite in the context of mega construction projects. Different factors that affect risk appetite were identified and categorized, following a literature study, as organizational, decision-makers, environmental, project, and miscellaneous factors. Some factors, e.g., goals and objectives, performance, risk propensity of the C.E.O and board members, and remuneration, increase an organization's risk appetite for mega project selection, and some 
factors, e.g., public opposition, rules and regulation, legal and regulatory, and politics, decrease risk appetite. Under various conditions, the nature of these factors' effect on an organization's risk appetite for megaproject selection, may alter. Some of these factors are the same as for the risk appetite of any kind of organization, but some factors are specific to project management and construction management. These factors may be applied to any kind of project-based organization and any size of a construction project. These insights may be utilized by policy makers, risk managers, and decision-makers to obtain a better understanding of the variables that influence an organization's risk appetite while selecting mega construction projects and analysis thereof. Project selection based upon risk appetite will reduce failures, delays, and cost overruns in mega projects. Decision makers and risk managers may utilize these insights to have a better understanding and analysis of the drivers as well as impediments of their organization's risk appetite. Additionally, the factors can be utilized to decode and analyze rivals' risk appetites in order to acquire a better understanding of their risk-taking behavior. Researchers may utilize these elements to develop risk appetite models, as well as analyze their interrelationships and the mediating or moderating effects. This research is based upon risk appetite of mega construction projects selection. Other researchers can use these factors for other than construction sector. These factors may not only be specific to selection and management of construction projects but can also be used in enterprise risk management and portfolio risk management.

Author Contributions: Conceptualization, S.U., N.A.M., M.Q.S. and A.H.; methodology, S.U., N.A.M., A.H. and R.N.L.; software, S.U. and R.N.L.; validation, N.A.M., R.N.L. and R.A.; formal analysis, S.U., N.A.M., M.Q.S., A.H., R.N.L. and R.A.; investigation, S.U., R.N.L. and R.A.; resources, S.U., N.A.M. and M.Q.S.; data curation, S.U.; writing-original draft preparation, S.U.; writing-review and editing, S.U., N.A.M., M.Q.S., A.H., R.N.L. and R.A.; supervision, N.A.M., M.Q.S. and A.H.; project administration, S.U., N.A.M. and M.Q.S. All authors have read and agreed to the published version of the manuscript.

Funding: This research received no external funding.

Data Availability Statement: Data available on request due to restrictions, e.g., privacy or ethical. The data presented in this study are available on request from the corresponding author. The data are not publicly available due to privacy and anonymity of respondents.

Acknowledgments: The authors acknowledge the contribution of all respondents and facilitators who helped in study.

Conflicts of Interest: The authors declare no conflict of interest.

\section{References}

1. Flyvbjerg, B. What you should know about megaprojects and why: An overview. Proj. Manag. J. 2014, 45, 6-19. [CrossRef]

2. Chen, H.; Jin, Z.; Su, Q.; Yue, G. The roles of captains in megaproject innovation ecosystems: The case of the Hong Kong-ZhuhaiMacau Bridge. Eng. Constr. Archit. Manag. 2021, 28, 662-680. [CrossRef]

3. Liu, H.; Yu, Y.; Sun, Y.; Yan, X. A system dynamic approach for simulation of a knowledge transfer model of heterogeneous senders in mega project innovation. Eng. Constr. Archit. Manag. 2021, 28, 681-705. [CrossRef]

4. Lin, H.; Zeng, S.; Ma, H.; Zeng, R.; Tam, V.W.Y. An indicator system for evaluating megaproject social responsibility. Int. J. Proj. Manag. 2017, 35, 1415-1426. [CrossRef]

5. Ma, H.; Zeng, S.; Lin, H.; Chen, H.; Shi, J.J. The societal governance of megaproject social responsibility. Int. J. Proj. Manag. 2017, 35, 1365-1377. [CrossRef]

6. Chen, H.; Su, Q.; Zeng, S.; Sun, D.; Shi, J.J. Avoiding the innovation island in infrastructure mega-project. Front. Eng. Manag. 2018, 5, 109-124. [CrossRef]

7. Lehtinen, J.; Peltokorpi, A.; Artto, K. Megaprojects as organizational platforms and technology platforms for value creation. Int. J. Proj. Manag. 2019, 37, 43-58. [CrossRef]

8. Nyarirangwe, M.; Babatunde, O.K. Megaproject complexity attributes and competences: Lessons from IT and construction projects. Int. J. Inf. Syst. Proj. Manag. 2019, 7, 77-99.

9. Dimitriou, H.T.; Low, N.; Sturup, S.; Zembri, G.; Campagnac, E.; Kaparos, G.; Skayannis, P.; Muromachi, Y.; Iwakura, S.; Itaya, K.; et al. What constitutes a "successful" mega transport project?/Leadership, risk and storylines: The case of the Sydney Cross City Tunnel/The case of the LGV Méditerranée high speed railway line/Dealing with context and uncertainty in the development of the Athen. Plan. Theory Pract. 2014, 15, 389-430. [CrossRef] 
10. Davies, A.; Mackenzie, I. Project complexity and systems integration: Constructing the London 2012 Olympics and Paralympics Games. Int. J. Proj. Manag. 2014, 32, 773-790. [CrossRef]

11. Ma, H.; Liu, Z.; Zeng, S.; Lin, H.; Tam, V.W.Y. Does megaproject social responsibility improve the sustainability of the construction industry? Eng. Constr. Archit. Manag. 2019, 27, 975-996. [CrossRef]

12. Merrow, E.W. Industrial Megaprojects: Concepts, Strategies, and Practices for Success; EBL-Schweitzer; Wiley: Hoboken, NJ, USA, 2011; Volume 1, pp. 1-9. ISBN 9780470938829.

13. Gil, N.; Pinto, J.K. Polycentric organizing and performance: A contingency model and evidence from megaproject planning in the UK. Res. Policy 2018, 47, 717-734. [CrossRef]

14. Flyvbjerg, B.; Turner, J.R. Do classics exist in megaproject management? Int. J. Proj. Manag. 2018, 36, 334-341. [CrossRef]

15. Project Management Institute. The Standard for Risk Management in Portfolios, Programs, and Projects; PMI Global Standard; Project Management Institute: Newtown Square, PA, USA, 2019; ISBN 9781628255652.

16. Project Management Institute. A Guide to the Project Management Body of Knowledge (PMBOK ${ }^{\circledR}$ Guide), 6th ed.; PMBOK ${ }^{\circledR}$ Guide; Project Management Institute: Newtown Square, PA, USA, 2017; ISBN 9781628253900.

17. Research and Markets. Growth Opportunities in the Global Construction Industry; Research and Markets: Dublin, Ireland, 2022; Volume 1, pp. 1-10.

18. Winch, G.M. Managing Construction Projects, 2nd ed.; Wiley: Hoboken, NJ, USA, 2009; pp. 1-15. ISBN 9781405184571.

19. Jayasudha, K.; Vidivelli, B. Analysis of major risks in construction projects. ARPN J. Eng. Appl. Sci. 2016, 11, 6943-6950.

20. Siraj, N.B.; Fayek, A.R. Risk identification and common risks in construction: Literature review and content analysis. J. Constr. Eng. Manag. 2019, 145, 3119004. [CrossRef]

21. Crickette, G.; Demian, R.; Fox, C.; Hach, J.; Makomaski, J.; Mazumdar, R.; McGuire, R. Exploring Risk Appetite and Tolerance. RIMS Exec. Rep. 2012. Available online: https://ermgovernance.com/Resources/RIMS_Exploring_Risk_Appetite_Risk_ Tolerance_0412.pdf (accessed on 18 December 2021).

22. Hillson, D. How much risk is too much risk? Understanding risk appetite. In Proceedings of the PMI Global Congress Proceedings, PMI ${ }^{\circledR}$ Global Congress 2012-North America, Vancouver, BC, Canada, 23 October 2012; pp. 1-7.

23. Gontarek, W. Risk governance of financial institutions: The growing importance of risk appetite and culture. J. Risk Manag. Financ. Inst. 2016, 9, 120-129.

24. Hillson, D.; Murray-Webster, R. A Short Guide to Risk Appetite, 1st ed.; Routledge: England, UK, 2012 ; pp. 1-7.

25. Baldan, C.; Geretto, E.; Zen, F. A quantitative model to articulate the banking risk appetite framework. J. Risk Manag. Financ. Inst. 2016, 9, 175-196.

26. Bromiley, P.; McShane, M.; Nair, A.; Rustambekov, E. Enterprise risk management: Review, critique, and research directions. Long Range Plann. 2015, 48, 265-276. [CrossRef]

27. Hillson, D.; Doctor, R. Using risk appetite and risk attitude to support appropriate risk taking: A new taxonomy and model. $J$. Proj. Progr. Portf. Manag. 2011, 2, 29-46.

28. Qadan, M. Risk appetite, idiosyncratic volatility and expected returns. Int. Rev. Financ. Anal. 2019, 65, 101372. [CrossRef]

29. Qadan, M.; Idilbi-Bayaa, Y. Risk appetite and oil prices. Energy Econ. 2020, 85, 104595. [CrossRef]

30. Woods, J.J.; Seychell, S.; Ozen, E.; Spiteri, J.; Suban, R.; Grima, S. Explaining Heterogeneity in Risk Appetite and Tolerance: The Turkish Case. In Contemporary Issues in Audit Management and Forensic Accounting; (Contemporary Studies in Economic and Financial Analysis, Vol. 102); Emerald Publishing Limited: Bingley, UK, 2020; Volume 102, pp. 111-130.

31. Etula, E. Broker-dealer risk appetite and commodity returns. J. Financ. Econom. 2013, 11, 486-521. [CrossRef]

32. Hassani, B. Risk Appetite in Practice: Vulgaris Mathematica. IUP J. Financ. Risk Manag. 2015, 7, 7-22.

33. Le, T.H.; Arcodia, C. Risk perceptions on cruise ships among young people: Concepts, approaches and directions. Int. J. Hosp. Manag. 2018, 69, 102-112. [CrossRef]

34. Wen, H.; Kwon, J. Restaurant servers' risk perceptions and risk communication-related behaviors when serving customers with food allergies in the US. Int. J. Hosp. Manag. 2017, 64, 11-20. [CrossRef]

35. Zhang, N.; Paraskevas, A.; Altinay, L. Factors that shape a hotel company's risk appetite. Int. J. Hosp. Manag. 2019, 77, 217-225. [CrossRef]

36. Aven, T. On the meaning and use of the risk appetite concept. Risk Anal. 2013, 33, 462-468. [CrossRef]

37. Berlinger, E.; Váradi, K. Risk Appetite. Public Financ. Q. 2015, 60, 49-62.

38. Taroun, A. Towards a better modelling and assessment of construction risk: Insights from a literature review. Int. J. Proj. Manag. 2014, 32, 101-115. [CrossRef]

39. Zou, P.X.W.; Zhang, G.; Wang, J. Understanding the key risks in construction projects in China. Int. J. Proj. Manag. 2007, 25, 601-614. [CrossRef]

40. Yuan, J.; Chen, K.; Li, W.; Ji, C.; Wang, Z.; Skibniewski, M.J. Social network analysis for social risks of construction projects in high-density urban areas in China. J. Clean. Prod. 2018, 198, 940-961. [CrossRef]

41. Fortunato III, B.R.; Hallowell, M.R.; Behm, M.; Dewlaney, K. Identification of safety risks for high-performance sustainable construction projects. J. Constr. Eng. Manag. 2012, 138, 499-508. [CrossRef]

42. Muralidhar, S.; Berlik, E. What's Your Risk Appetite? Helping Financial Advisors Better Serve Clients (by Quantifying KahnemanTversky's Value Function). J. Pers. Financ. 2017, 16, 20-36.

43. Gai, P.; Vause, N. Measuring investors' risk appetite. Int. J. Cent. Bank. 2006, 2, 167-188. [CrossRef] 
44. Dupuy, P. Pure indicator of risk appetite. Aust. Econ. Pap. 2009, 48, 18-33. [CrossRef]

45. Kaufmann, C.; Weber, M.; Haisley, E. The role of experience sampling and graphical displays on one's investment risk appetite. Manag. Sci. 2013, 59, 323-340. [CrossRef]

46. Belghitar, Y.; Clark, E.A. The effect of CEO risk appetite on firm volatility: An empirical analysis of financial firms. Int. J. Econ. Bus. 2012, 19, 195-211. [CrossRef]

47. Lam, J. Enterprise Risk Management: From Incentives to Controls; John Wiley \& Sons: Hoboken, NJ, USA, $2014 ;$ pp. $21-29$.

48. Manavizadeh, N.; Malek, S.; Vosoughi-Kia, R.; Farrokhi-Asl, H. An efficient risk based multi objective project selection approach considering environmental issues. Uncertain Supply Chain Manag. 2017, 5, 143-158. [CrossRef]

49. Oteng-Abayie, E.F.; Dramani, J.B. Time-frequency domain causality of prime building cost and macroeconomic indicators in Ghana: Implications for project selection. Constr. Manag. Econ. 2019, 37, 243-256. [CrossRef]

50. Kangari, R.; Riggs, L.S. Portfolio management in construction. Constr. Manag. Econ. 1988, 6, 161-169. [CrossRef]

51. Utomo, C.; Murti, F. Quantitative Method for Optimizing Decision in Project Selection. In Proceedings of the 2nd International Conference on Built Environment in Developing Countries, Penang, Malaysia, 3-4 December 2008.

52. Markowitz, H. Portfolio Selection; John Wiley \& Sons: Hoboken, NJ, USA, 1959; pp. 3-8.

53. Cyert, R.M.; March, J.G. A Behavioral Theory of the Firm: Blackwell Business; Blackwell: Cambridge, MA, USA, 1963; pp. 1-3.

54. Kai-Ineman, D.A.N.I.E.L.; Tversky, A. Prospect Theory: An Analysis of Decision under Risk. Econometrica 1979, 47, $263-291$. [CrossRef]

55. Staw, B.M.; Sandelands, L.E.; Dutton, J.E. Threat rigidity effects in organizational behavior: A multilevel analysis. Adm. Sci. Q. 1981, 501-524. [CrossRef]

56. Schoemaker, P.J.H. The expected utility model: Its variants, purposes, evidence and limitations. J. Econ. Lit. 1982, $529-563$.

57. Isen, A.M.; Patrick, R. The effect of positive feelings on risk taking: When the chips are down. Organ. Behav. Hum. Perform. 1983, 31, 194-202. [CrossRef]

58. Hambrick, D.C.; Mason, P.A. Upper echelons: The organization as a reflection of its top managers. Acad. Manag. Rev. 1984, 9, 193-206. [CrossRef]

59. Eisenhardt, K.M. Agency theory: An assessment and review. Acad. Manag. Rev. 1989, 14, 57-74. [CrossRef]

60. Wiseman, R.M.; Gomez-Mejia, L.R. A behavioral agency model of managerial risk taking. Acad. Manag. Rev. 1998, 23, 133-153. [CrossRef]

61. Chen, W.R.; Miller, K.D. Situational and institutional determinants of firms' R\&D search intensity. Strateg. Manag. J. 2007, $28,369-381$.

62. Gómez-Mejia, L.R.; Haynes, K.T.; Núñez-Nickel, M.; Jacobson, K.J.L.; Moyano-Fuentes, J. Socioemotional wealth and business risks in family-controlled firms: Evidence from Spanish olive oil mills. Adm. Sci. Q. 2007, 52, 106-137. [CrossRef]

63. Shimizu, K. Prospect theory, behavioral theory, and the threat-rigidity thesis: Combinative effects on organizational decisions to divest formerly acquired units. Acad. Manag. J. 2007, 50, 1495-1514. [CrossRef]

64. Eisenmann, T.R. The effects of CEO equity ownership and firm diversification on risk taking. Strateg. Manag. J. 2002, 23, 513-534. [CrossRef]

65. Wright, P.; Kroll, M.; Krug, J.A.; Pettus, M. Influences of top management team incentives on firm risk taking. Strateg. Manag. J. 2007, 28, 81-89. [CrossRef]

66. McNulty, T.; Florackis, C.; Ormrod, P. Boards of directors and financial risk during the credit crisis. Corp. Gov. Int. Rev. 2013, 21, 58-78. [CrossRef]

67. Sahaym, A.; Cho, S.Y.; Kim, S.K.; Mousa, F.-T. Mixed blessings: How top management team heterogeneity and governance structure influence the use of corporate venture capital by post-IPO firms. J. Bus. Res. 2016, 69, 1208-1218. [CrossRef]

68. Pablo, A.L.; Javidan, M. Thinking of a merger... Do you know their risk propensity profile. Organ. Dyn. 2002, 30, 206. [CrossRef]

69. Fessler, D.M.T.; Pillsworth, E.G.; Flamson, T.J. Angry men and disgusted women: An evolutionary approach to the influence of emotions on risk taking. Organ. Behav. Hum. Decis. Process. 2004, 95, 107-123. [CrossRef]

70. Delgado-Garcia, J.B.; De La Fuente-Sabaté, J.M.; De Quevedo-Puente, E. Too negative to take risks? The effect of the CEO's emotional traits on firm risk. Br. J. Manag. 2010, 21, 313-326. [CrossRef]

71. Panzano, P.C.; Roth, D. The decision to adopt evidence-based and other innovative mental health practices: Risky business? Psychiatr. Serv. 2006, 57, 1153-1161. [CrossRef]

72. Kull, T.J.; Oke, A.; Dooley, K.J. Supplier selection behavior under uncertainty: Contextual and cognitive effects on risk perception and choice. Decis. Sci. 2014, 45, 467-505. [CrossRef]

73. Mattana, P.; Petroni, F.; Rossi, S.P.S. A test for the too-big-to-fail hypothesis for European banks during the financial crisis. Appl. Econ. 2015, 47, 319-332. [CrossRef]

74. Bhagat, S.; Bolton, B.; Lu, J. Size, leverage, and risk-taking of financial institutions. J. Bank. Financ. 2015, 59, 520-537. [CrossRef]

75. Baird, I.S.; Thomas, H. Toward a contingency model of strategic risk taking. Acad. Manag. Rev. 1985, 10, 230-243. [CrossRef]

76. Bhatta, G. Don't just do something, stand there! Revisiting the Issue of Risks in Innovation in the Public Sector. Innov. J. Public Sect. Innov. J. 2003, 8, 1-12.

77. Rittenberg, L.; Martens, F. Understanding and communicating risk appetite. Enterp. Risk Manag. 2012, 18, 2019.

78. Tabak, B.M.; Fazio, D.M.; Cajueiro, D.O. The relationship between banking market competition and risk-taking: Do size and capitalization matter? J. Bank. Financ. 2012, 36, 3366-3381. [CrossRef] 
79. Jiménez, G.; Lopez, J.A.; Saurina, J. How does competition affect bank risk-taking? J. Financ. Stab. 2013, 9, 185-195. [CrossRef]

80. Hoque, H.; Andriosopoulos, D.; Andriosopoulos, K.; Douady, R. Bank regulation, risk and return: Evidence from the credit and sovereign debt crises. J. Bank. Financ. 2015, 50, 455-474. [CrossRef]

81. Cohen, D.A.; Dey, A.; Lys, T.Z. Corporate governance reform and executive incentives: Implications for investments and risk taking. Contemp. Account. Res. 2013, 30, 1296-1332. [CrossRef]

82. Carpenter, M.A.; Pollock, T.G.; Leary, M.M. Testing a model of reasoned risk-taking: Governance, the experience of principals and agents, and global strategy in high-technology IPO firms. Strateg. Manag. J. 2003, 24, 803-820. [CrossRef]

83. Bouwman, C.H.S.; Malmendier, U. Does a bank's history affect its risk-taking? Am. Econ. Rev. 2015, 105, 321-325. [CrossRef]

84. Chatzinikoli, T.; Toner, W. Leading effective business risk management. In Managing Business Risk: A Practical Guide to Protecting Your Business, 6th ed.; Kogan Page Limited: London, UK, 2009.

85. Govindarajan, D. Corporate risk appetite: Ensuring board and senior management accountability for risk. In ICMA Cent. Discuss. Pap.; ICMA Centre: England; Available online: https:/ / ssrn.com/abstract=1962126 (accessed on 18 December 2021).

86. Harwood, I.A.; Ward, S.C.; Chapman, C.B. A grounded exploration of organisational risk propensity. J. Risk Res. 2009, 12, 563-579. [CrossRef]

87. Kirchherr, J.; Charles, K.J.; Walton, M.J. Multi-causal pathways of public opposition to dam projects in Asia: A fuzzy set qualitative comparative analysis (fsQCA). Glob. Environ. Chang. 2016, 41, 33-45. [CrossRef]

88. Martinez-Miera, D.; Repullo, R. Does competition reduce the risk of bank failure? Rev. Financ. Stud. 2010, $23,3638-3664$. [CrossRef]

89. Patton, M.Q. How to Use Qualitative Methods in Evaluation; Sage: Thousand Oaks, CA, USA, 1987; pp. 37-39.

90. Patton, M.Q. Qualitative Research E Evaluation Methods: Integrating Theory and Practice; SAGE Publications: Thousand Oaks, CA, USA, 2014; pp. 55-60. ISBN 9781483314815.

91. Saunders, M.; Lewis, P.; Thornhill, A. Research Methods for Business Students; Always Learning; Prentice Hall: Hoboken, NJ, USA, 2009; pp. 318-350. ISBN 9780273716860.

92. Marshall, M.N. Sampling for qualitative research. Fam. Pract. 1996, 13, 522-526. [CrossRef]

93. Payne, G.; Payne, J. Key Concepts in Social Research; Sage: Thousand Oaks, CA, USA, 2004; pp. $134-138$.

94. Krueger, R.A.; Casey, M.A. Focus Groups: A Practical Guide for Applied Research; SAGE Publications: Thousand Oaks, CA, USA, 2009; pp. 185-195. ISBN 9781412969475.

95. Galvin, R. How many interviews are enough? Do qualitative interviews in building energy consumption research produce reliable knowledge? J. Build. Eng. 2015, 1, 2-12. [CrossRef]

96. Ritchie, J.; Lewis, J.; Nicholls, C.M.; Ormston, R. Qualitative Research Practice: A Guide for Social Science Students and Researchers; Sage: Thousand Oaks, CA, USA, 2013; pp. 194-197.

97. Lincoln, Y.S.; Guba, E.G. Naturalistic Inquiry; Sage: Thousand Oaks, CA, USA, 1985; pp. $289-331$.

98. Braun, V.; Clarke, V. Using thematic analysis in psychology. Qual. Res. Psychol. 2006, 3, 77-101. [CrossRef]

99. Mohammed, H.J. The optimal project selection in portfolio management using fuzzy multi-criteria decision-making methodology. J. Sustain. Financ. Invest. 2021, 1-17. [CrossRef]

100. Beringer, C.; Jonas, D.; Kock, A. Behavior of internal stakeholders in project portfolio management and its impact on success. Int. J. Proj. Manag. 2013, 31, 830-846. [CrossRef]

101. Hernández, C.; Pajares, J.; López-Paredes, A. A portfolio inspired metric for project selection in construction management. Organ. Technol. Manag. Constr. Int. J. 2011, 3, 246-268.

102. Cooper, R.G.; Edgett, S.J. Ten ways to make better portfolio and project selection decisions. PDMA Vis. Mag. 2006, $30,11-15$.

103. Dwivedula, R. Human Resource Management in Project Management: Ideas at the CUSP. Eur. Proj. Manag. J. $2019,9,34-41$. [CrossRef]

104. Keegan, A.; Ringhofer, C.; Huemann, M. Human resource management and project based organizing: Fertile ground, missed opportunities and prospects for closer connections. Int. J. Proj. Manag. 2018, 36, 121-133. [CrossRef]

105. Pinto, J.K. Understanding the role of politics in successful project management. Int. J. Proj. Manag. 2000, 18, 85-91. [CrossRef]

106. Hurlimann, A.; Dolnicar, S. When public opposition defeats alternative water projects-The case of Toowoomba Australia. Water Res. 2010, 44, 287-297. [CrossRef] [PubMed]

107. Liu, B.; Hu, Y.; Wang, A.; Yu, Z.; Yu, J.; Wu, X. Critical factors of effective public participation in sustainable energy projects. J. Manag. Eng. 2018, 34, 4018029. [CrossRef]

108. Mubita, A.; Libati, M.; Mulonda, M. The importance and limitations of participation in development projects and programmes. Eur. Sci. J. 2017, 13, 238-251. [CrossRef]

109. Ling, F.Y.Y.; Hoi, L. Risks faced by Singapore firms when undertaking construction projects in India. Int. J. Proj. Manag. 2006, 24, 261-270. [CrossRef]

110. Sainati, T.; Locatelli, G.; Smith, N. Project financing in nuclear new build, why not? The legal and regulatory barriers. Energy Policy 2019, 129, 111-119. [CrossRef]

111. Mouraviev, N.; Kakabadse, N.K. Legal and regulatory barriers to effective public-private partnership governance in Kazakhstan. Int. J. Public Sect. Manag. 2015, 28, 181-197. [CrossRef]

112. Alyamani, R.; Long, S. The application of fuzzy Analytic Hierarchy Process in sustainable project selection. Sustainability 2020, 12, 8314. [CrossRef] 
113. Kudratova, S.; Huang, X.; Zhou, X. Sustainable project selection: Optimal project selection considering sustainability under reinvestment strategy. J. Clean. Prod. 2018, 203, 469-481. [CrossRef]

114. Solangi, Y.A.; Tan, Q.; Khan, M.W.A.; Mirjat, N.H.; Ahmed, I. The selection of wind power project location in the Southeastern Corridor of Pakistan: A factor analysis, AHP, and fuzzy-TOPSIS application. Energies 2018, 11, 1940. [CrossRef]

115. Sharma, S.; Bansal, V.K. Location-based planning and scheduling of highway construction projects in hilly terrain using GIS. Can. J. Civ. Eng. 2018, 45, 570-582. [CrossRef]

116. Lee, B.; Jung, N.; Kim, J. A Study on the Location Assessment of Rural Village Construction Project. J. Korean Soc. Agric. Eng. 2019, 61, 97-103.

117. Cheng, E.W.L.; Li, H. Exploring quantitative methods for project location selection. Build. Environ. 2004, 39, 1467-1476. [CrossRef]

118. Henderson, L.S.; Stackman, R.W. An exploratory study of gender in project management: Interrelationships with role, location, technology, and project cost. Proj. Manag. J. 2010, 41, 37-55. [CrossRef]

119. Rosato, M. Go small for project success. PMWJ 2018, 7, 1-10.

120. der Waldt, G. The uniqueness of public sector project management: A contextual perspective. Politeia 2011, $30,66-87$.

121. Ruchala, L. V The influence of budget goal attainment on risk attitudes and escalation. Behav. Res. Account. 1999, 11, 161.

122. Harvey, P.; Victoravich, L.M. The influence of forward-looking antecedents, uncertainty, and anticipatory emotions on project escalation. Decis. Sci. 2009, 40, 759-782. [CrossRef] 